\title{
Conservation biology and management of the endangered Oxleyan pygmy perch Nannoperca oxleyana in Australia
}

\author{
James T. Knight ${ }^{1, *}$, Angela H. Arthington ${ }^{2}$, Gabrielle S. Holder ${ }^{1}$, R. Bill Talbot ${ }^{1}$ \\ ${ }^{1}$ NSW Department of Trade and Investment, Regional Infrastructure and Services, Port Stephens Fisheries Institute, \\ Nelson Bay, New South Wales 2315, Australia \\ ${ }^{2}$ Australian Rivers Institute and DIVERSITAS, Griffith University, Nathan, Queensland 4111, Australia
}

\begin{abstract}
The global biodiversity crisis particularly affects freshwater fishes. Currently, $20 \%$ of Australia's highly endemic freshwater fishes are formally recognised as being of conservation concern under national, state and territory listings. Four of the 5 described species of Nannoperca (Percichthyidae) are threatened with extinction, with $N$. oxleyana Whitley listed as endangered under Australian legislation and internationally by the IUCN. National recovery planning has commenced with the objective of returning this species to a position of 'viability in nature' in New South Wales (NSW) and Queensland. This paper describes the conservation biology of $N$. oxleyana, providing a case history for a small species of no commercial importance threatened by the classical triumvirate of habitat degradation and loss; small, declining and fluctuating populations driven more by environmental conditions than demographic forces; and the effects of introduced species. A process for declaring critical habitat for N. oxleyana has commenced in NSW. Habitat protection involves managing threats, including run-off originating from unsealed roads, herbicide use, fire management activities and disturbance by recreational users such as 4 -wheel drivers and campers. Information on the distribution and breeding patterns of $N$. oxleyana has been provided to local and state government authorities to assist in managing drainage and development schemes that might impact $N$. oxleyana habitat. Monitoring has confirmed the persistence of many $N$. oxleyana populations in both jurisdictions.
\end{abstract}

KEY WORDS: Endangered fishes $\cdot$ Conservation biology $\cdot$ Threat analysis $\cdot$ Recovery planning

\section{INTRODUCTION}

Global biological diversity is rapidly declining as a consequence of human activities (Sala et al. 2000, Sutherland et al. 2009). Fresh waters and their fishes are experiencing major losses in diversity (Duncan \& Lockwood 2001, Dudgeon et al. 2006). The endemic fish fauna of Australia is no exception, with the geographic range and abundance of many species declining significantly since European settlement (Wager \& Jackson 1993, Pusey et al. 2004). Currently, of the continent's 258 freshwater fish species (Hoese et al. 2006a), 20\% (51 species) are listed as threatened under Commonwealth, State and/or Territory legislation.

Australian Commonwealth, State and Territory legislation provides for the protection, conservation and recovery of threatened species, populations and ecological communities. Statutory recovery plans aim to return a species, population or ecological community to a position of 'viability in nature', and outline the actions that government agencies and other organisa- 
tions have agreed upon to promote recovery. Recovery planning largely involves mitigating human impacts by implementing management approaches based on a strong understanding of a species' conservation biology (Dudgeon et al. 2006). The scientific knowledge base must include an understanding of a species' evolutionary biogeography, patterns of genetic variation, habitat associations and environmental tolerances, life history strategy and population dynamics within the context of the biophysical factors and threatening processes influencing long-term viability (Burgman \& Lindenmayer 1998, Meffe et al. 2006). Unfortunately, much of this information is lacking for many of Australia's threatened fishes (Wager \& Jackson 1993, Morris et al. 2001, Pusey et al. 2004).

The present paper reviews known aspects of the conservation biology of, and current threats to, the Oxleyan pygmy perch Nannoperca oxleyana Whitley, a small, threatened freshwater fish endemic to Australia. This synthesis of information is discussed in the context of the recovery planning process and the actions set out in the national recovery plan for $N$. oxleyana through which detailed biological information is utilised to help restore populations to a position of viability in nature. The value of recovery planning is demonstrated not only through these conservation activities but also by the fact that many of these measures are founded on scientific research driven by initial recovery planning efforts (Arthington 1996), followed by the national recovery plan (NSW DPI 2005).

\section{TAXONOMY AND CONSERVATION LISTING}

Pygmy perches in the family Percichthyidae (Jerry et al. 2001, Hoese et al. 2006b) are a group of small ( $\leq 90 \mathrm{~mm}$ total length) freshwater fishes endemic to the freshwater drainage systems of southern Australia. Four of the 5 described species of Nannoperca are threatened with extinction (Morris et al. 2001, IUCN 2009), with N. oxleyana formally recognised as the most threatened species. This species is listed as Endangered by the International Union for Conservation of Nature (IUCN 2009), the Australian Society for Fish Biology, under the Australian Commonwealth 'Environment Protection and Biodiversity Conservation Act 1999' and under the New South Wales (NSW) 'Fisheries Management Act 1994'. It is also listed as vulnerable under the Queensland 'Nature Conservation Act 1992'. A National Recovery Plan for N. oxleyana was prepared in 2005 (NSW DPI 2005).

\section{SPECIES DESCRIPTION AND BIOGEOGRAPHY}

Nannoperca oxleyana is a small fish with a maximum total length of $60 \mathrm{~mm}$ but more commonly growing to $45 \mathrm{~mm}$ and $2.8 \mathrm{~g}$. Meristics include 6 to 8 dorsal spines, 7 to 9 dorsal rays, 3 anal spines and 7 to 9 anal rays. The body is moderately compressed and lacks a lateral line. The mouth is relatively small with jaws reaching to below the anterior part of the pupil. The body colour is light brown to olive, darker on the back, with paler, mottled sides and 3 to 4 patchy dark brown bars extending from head to tail (Fig. 1). The opercular flap has a blue iridescent sheen, and the ctenoid scales have dusky outlines. A round black spot with orange margin is prominent at the base of the truncated caudal fin. Fins are mainly clear except during breeding, when males develop more intense red and brown fin and body colouration than females and have jet black pelvic fins (Pusey et al. 2004, Knight et al. 2007a).

Nannoperca oxleyana has the most northerly geographic range of the genus. The species typically occupies shallow, swampy habitats in dystrophic freshwater streams, lakes and swamps draining through sandy lowland wallum (Banksiadominated heathland) ecosystems of north-eastern NSW and south-eastern Queensland (Fig. 2). It has a very restricted, fragmented and patchy distribution along approximately $534 \mathrm{~km}$ of coastline, extending from Coongul Creek on Fraser Island, Queensland $\left(25^{\circ} 16^{\prime} \mathrm{S}, 153^{\circ} 09^{\prime} \mathrm{E}\right)$ south to an unnamed tributary of the Wooli River, NSW $\left(29^{\circ} 56^{\prime} \mathrm{S}\right.$, $153^{\circ} 09^{\prime} \mathrm{E}$ ) (Keller \& Brown 2008, Knight \& Arthington 2008). Since 1990, N. oxleyana has been documented from 110 water bodies within 80 discrete drainage systems in 5 mainland catchments and on 3 offshore islands (Table 1; Knight \& Arthington 2008, J. T. Knight unpubl. data), with $72 \%$ of the discrete systems located in NSW. Indeed, $N$. oxleyana is rarer and has a more fragmented distribution in south-east Queensland. Small populations inhabit 6 isolated, mainland drainages, while the remainder are distributed across Fraser, Moreton and North Stradbroke Islands (Fig. 2). Throughout its range, most water bodies supporting this species are situated within $8 \mathrm{~km}$ of the coast at elevations of less than $30 \mathrm{~m}$ above sea level (Knight \& Arthington 2008). There is evidence of a range contraction in the south over the last $30 \mathrm{yr}$, and $N$. oxleyana is no longer found in several localities where it was collected between 1929 and 1976 (Bookram Creek, Cassons Creek and near Coraki, NSW; Fig. 2). 


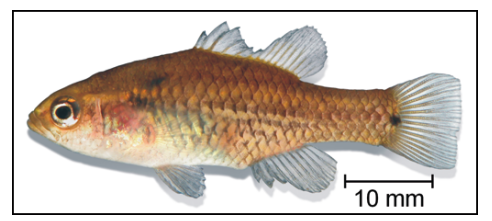

Fig. 1. Nannoperca oxleyana Whitley. Photo: NSW Department of Trade and Investment

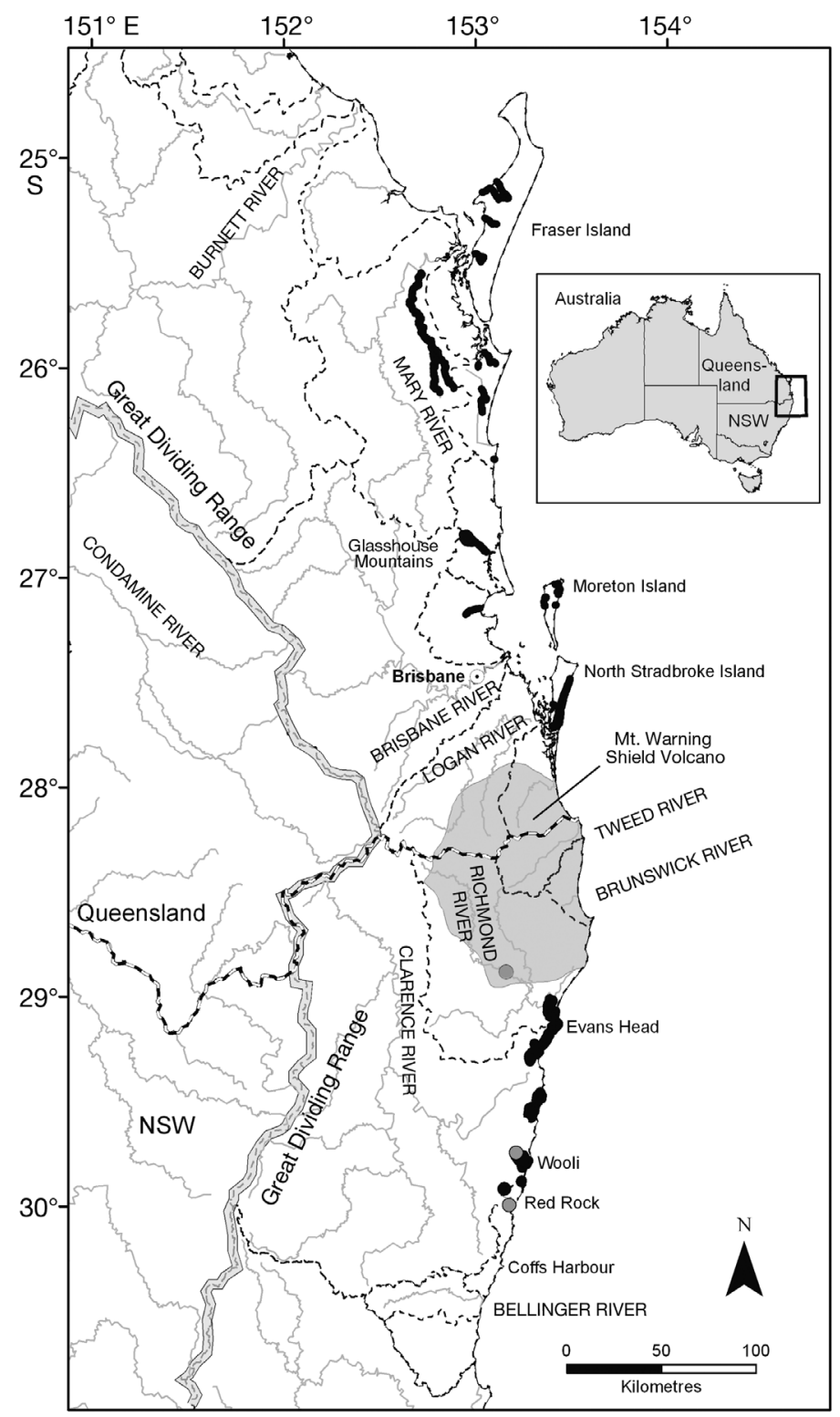

Fig. 2. Nannoperca oxleyana. Currently known distribution of the Oxleyan pygmy perch (black shading) and locations where the species has been historically recorded but is now presumed extinct (grey circles). The coastal catchments (dashed lines) east of the Great Dividing Range, the Queensland/New South Wales state border (thick black and white line) and the extent of the Mount Warning shield volcano (grey shading) are depicted
Prior to the commencement of the national recovery planning process in 2000, Nannoperca oxleyana had been recorded from only a few locations in NSW (Fig. 3) and little was known of its distribution and conservation status (Knight \& Butler 2004). A need for baseline data stimulated an extensive survey of over 300 sites in the state's north-east. The species is now known to inhabit 74 water bodies within 58 discrete systems draining the coastal floodplains of the Richmond and Clarence Rivers (Table 1, Fig. 2). The prevalence of $N$. oxleyana on NSW coastal floodplains has been attributed to intermittent connection among water bodies during high rainfall events or large floods emanating from the Richmond and Clarence Rivers. These conditions may facilitate dispersal, thereby allowing the species to colonise new systems and/or to recolonise previously disturbed areas within a subcatchment (Knight \& Arthington 2008, Knight et al. 2009). However, distinct genetic differentiation and hence restricted gene flow is evident among these subcatchments. Likewise, high levels of genetic structuring have been found among mainland and insular populations studied in Queensland, and it is inferred that they have diverged from each other as a result of extremely limited dispersal (Hughes et al. 1999, Knight et al. 2009). Contemporary gene flow among interconnected swampy seepages and lakes on Moreton Island is also evident (Hughes et al. 1999). At a larger spatial scale, the mainland Queensland and NSW populations no longer appear to intermix as they are separated by approximately $250 \mathrm{~km}$ of coastline (Fig. 2).

The underlying causes of the current geographic distribution gap between Queensland and NSW populations are unclear as there are no historical records of the occurrence of Nannoperca oxleyana along this coastal strip. Possible reasons include that the species never dispersed into catchments forming the distribution gap, or that it was once present there but became locally extinct as a consequence of natural or human interventions. With regard to the latter, human-induced habitat destruction, degradation and fragmentation within the Tweed and Brunswick catchments (Fig. 2) may have caused the localised extinction of $N$. oxleyana in this part of its range. These catchments lack large floodplains like those inhabited by $N$. oxleyana further south in the Richmond and Clarence catchments, which appear to provide pathways for dispersal and recolonisation, thereby reducing the probability of extinction (Unmack 2001). The species' absence from this area also coincides with the presence of the Mount Warning shield volcano (Fig. 2), which formed 23.5 to 20.5 million yr ago, and was responsible for the formation 
Table 1. Nannoperca oxleyana. Number of Oxleyan pygmy perch localities documented since 1990 in Queensland and New South Wales, Australia. Tributary streams and lentic bodies within larger discrete drainage systems were treated as separate water bodies. Table updated from Knight \& Arthington (2008)

\begin{tabular}{|lcccc|}
\hline Location & $\begin{array}{c}\text { River/ } \\
\text { tributary }\end{array}$ & $\begin{array}{c}\text { Lake/ } \\
\text { pond/dam }\end{array}$ & Swamp & $\begin{array}{c}\text { Discrete } \\
\text { drainage }\end{array}$ \\
\hline Queensland & & & & \\
Mary River catchment & 2 & 0 & 0 & 1 \\
Noosa River catchment & 10 & 0 & 0 & 4 \\
Maroochy River catchment & 3 & 0 & 0 & 1 \\
Fraser Island & 5 & 0 & 0 & 5 \\
Moreton Island & 11 & 2 & 0 & 8 \\
North Stradbroke Island & 1 & 1 & 1 & 3 \\
Total & 32 & 3 & 1 & 22 \\
NSW & & & & \\
Richmond River catchment & 23 & 12 & 9 & 31 \\
Clarence River catchment & 14 & 6 & 10 & 27 \\
Total & 37 & 18 & 19 & 58 \\
\hline
\end{tabular}

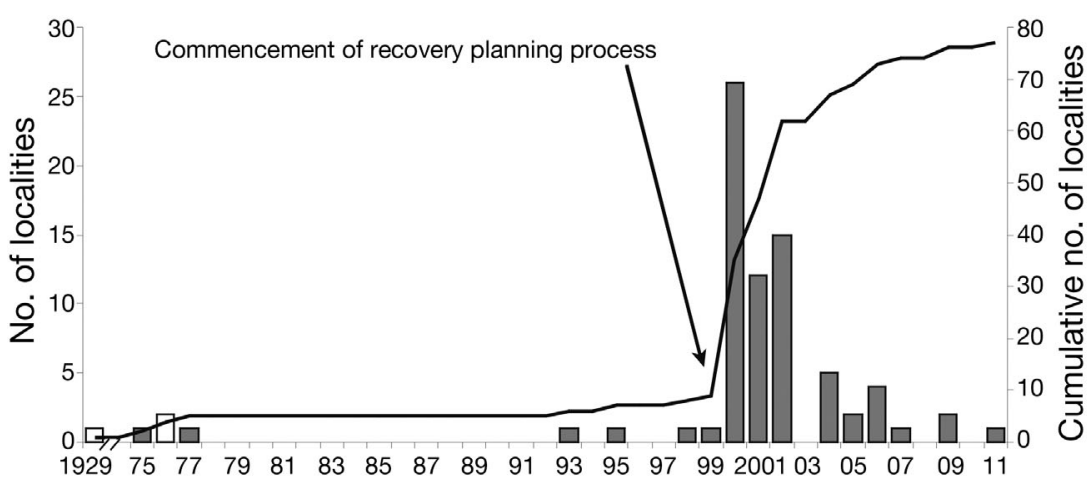

Fig. 3. Nannoperca oxleyana. Time-line of initial discovery of water bodies inhabited by the Oxleyan pygmy perch in New South Wales. Grey bars: number of new record localities in a given year that are known to currently support the species. White bars: number of previously recorded localities that no longer support the species. Black line: cumulative number of new N. oxleyana locality records over time

and super-imposition of radial drainage within the species distribution gap and major drainage disruption in adjacent catchments (Ollier 1995, Graham 2004a). The radial drainages associated with Mount Warning may have remained isolated thereby impeding colonisation of catchments in this area. The absence of $N$. oxleyana also conspicuously coincides with areas in northern NSW and southern Queensland inundated by marine transgressions 6500 to 4000 yr ago, when sea levels were approximately 1 to $1.5 \mathrm{~m}$ higher than at present (Lambeck \& Nakada 1990, Graham 2004b, Knight in press). These processes may have fragmented the distribution of $N$. oxleyana through extinction or impeded dispersal into particular catchments. A combination of past volcanism, recent marine transgressions and/or anthropogenic impacts is plausible, as are climatic conditions such as droughts, which may have caused the localised extinction of populations with limited dispersal opportunities (Unmack 2001, Matthews \& Marsh-Matthews 2003).

Despite the current fragmentation of the Queensland and NSW populations, recent historic connectivity appears to have existed (Knight et al. 2009). Indeed, opportunities for northward and southward gene flow may have existed as recently as $8000 \mathrm{yr} \mathrm{BP}$, at the end of the last glacial period, when lower sea levels facilitated shared confluences between adjacent drainages in northern NSW and those in south-eastern Queensland (Lambeck \& Nakada 1990, Hughes et al. 1999, Page \& Hughes 2007, Knight et al. 2009). Genetic data also suggest another range expansion around 18000 yr BP (Knight et al. 2009) consistent with lower sea levels during the last glacial maximum (Neal \& Stock 1986).

\section{BIOLOGY AND ECOLOGY}

Integral to the conservation and management of threatened species is an understanding of the ecology of small, declining and fluctuating populations (Meffe \& Vrijenhoek 1988, Burgman \& Lindenmayer 1998, Frankham 2005). Population conservation must be based on an understanding of the demographic processes of birth, death and migration linked to the vagaries of the environment in which populations exist (Dunning et al. 2006). Fish population dynamics are also influenced by life history characteristics (e.g. size at first reproduction, larval development), as these play an important role in long-term population trends and the evolution of population characteristics (Dunning et al. 2006).

The available information on the life history and ecological characteristics of Nannoperca oxleyana supports the notion that this species has an opportunistic life strategy (Table 2; Knight 2000). Species with this strategy are characterised by a high growth rate, early maturity at a small size, high reproductive output, a high mortality rate and, as a consequence, 
fluctuating population sizes driven more by environmental conditions than demographic forces (Winemiller \& Rose 1992, Olden \& Kennard 2010). This strategy is most evident in those populations inhabiting the source and sink floodplain habitats of the Richmond and Clarence Rivers of coastal NSW (Knight et al. 2007a).

Nannoperca oxleyana is further characterised by its habitat associations (Knight \& Arthington 2008). It typically occupies relatively pristine, sheltered habitats (aquatic vegetation, undercut banks, rootlets, litter and woody debris) with slow-flowing, fresh (conductivity $<830 \mu \mathrm{S} \mathrm{cm}^{-1}$ ), acidic ( $\mathrm{pH}$ range 3.32 to 6.9 ) and well-oxygenated (mean dissolved oxygen saturation $65.8 \%, 6.42 \mathrm{mg} \mathrm{l}^{-1}$ ) waters. Large population fluctuations linked to patterns of rainfall and drought have been documented in the wild (Arthington 1996, Knight 2000, Knight et al. 2007a), and there is evi- dence that anthropogenic habitat disturbances cause localised population declines and extinctions (Arthington \& Marshall 1993, Arthington 1996, Knight 2000, 2008, in press, Knight \& Arthington 2008). Hence, while large population sizes are achievable in undisturbed habitats, any reduction in the quality of habitat or other variations in the preferred environmental regime may result in substantial decreases in population size.

Given that population densities appear to be governed less by demographic processes and more by independent environmental stochasticity, management initiatives focused on maintaining and rehabilitating habitats, dispersal corridors and environmental conditions supporting Nannoperca oxleyana are likely to be more beneficial to the conservation of this species than activities such as stock enhancement aimed at increasing recruitment.

Table 2. Nannoperca oxleyana. Life history and ecological characteristics of the Oxleyan pygmy perch. Table adapted from Pusey et al. (2004). SL: standard length (distance from tip of snout to hypural crease); LBL: live body length (distance from tip of snout to the notochord tip for live preflexion and flexion larvae or equivalent to SL for live post-flexion larvae); TL: total length (distance from tip of snout to tip of caudal fin); Qld: Queensland; dph: days post hatch

\begin{tabular}{|c|c|}
\hline Parameter & Information \\
\hline Minimum age at maturity & $\begin{array}{l}\text { In wild: females: } 0.7 \mathrm{yr}^{\mathrm{c}} \text {; males: } 1.5 \mathrm{yr}^{\mathrm{c}} \\
\text { In aquaria: } 4-5 \mathrm{mo}\end{array}$ \\
\hline Minimum length of mature females & 19 mm SL in Spitfire Ck, Qld; 20 mm TL near Evans Head, NSW ${ }^{a}$ \\
\hline Minimum length of mature males & $19 \mathrm{~mm}$ SL in Spitfire Ck, Qld; 23 mm TL near Evans Head, NSW ${ }^{a}$ \\
\hline Longevity & In wild: $6.5 \mathrm{yr}^{\mathrm{c}}$; in aquaria: $>6 \mathrm{yr}^{\mathrm{c}}$ \\
\hline Sex ratio & Unknown \\
\hline Occurrence of ripe fish & In wild: all year ${ }^{\mathrm{a}}$ i in aquaria: September-May ${ }^{\mathrm{a}}$ \\
\hline Peak spawning activity & In wild: October-December and February-April ${ }^{\mathrm{a}}$ \\
\hline Critical temperature for spawning & In wild and aquaria: water temperature $\geq 16.6^{\circ} \mathrm{C}^{\mathrm{a}}$ \\
\hline Inducement to spawning & In wild and aquaria: water temperature $\geq 16.6^{\circ} \mathrm{C}$, day length $\geq 10.7 \mathrm{~h}^{\mathrm{a}}$ \\
\hline Mean gonadosomatic index of ripe fish & $\begin{array}{l}\text { In wild: females: } 3.3-4.1 \%^{\mathrm{a}} \text {; males: } 0.6-0.7 \%^{\mathrm{a}} \\
\text { In aguaria: females: } 4.2 \%^{\mathrm{a}} \text { : males: } 0.7 \%^{\mathrm{a}}\end{array}$ \\
\hline Mean batch fecundity (BF) & In wild and aquaria: 7.8 eggs fish ${ }^{-1} \mathrm{~d}^{-1}$ a \\
\hline Mean total (TF) and relative fecundity (RF) & In aquaria: $\mathrm{TF}=1323$ eggs fish $^{-1} \mathrm{a}_{;} \mathrm{RF}=589$ eggs g $^{-1} \mathrm{a}$ \\
\hline Fecundity/TL relationships & In aquaria: $\mathrm{BF}=-12.129+0.383 \mathrm{TL}^{\mathrm{a}} ; \mathrm{TF}=-4522.7+0.383 \mathrm{TL}^{\mathrm{a}}$ \\
\hline Egg diameter & In aquaria at $25 \pm 1^{\circ} \mathrm{C}: 0.98-1.10 \mathrm{~mm}^{\mathrm{b}}$ \\
\hline Mean frequency of spawning & In aquaria: $57 \%$ of days in a 256 d spawning period ${ }^{a}$ \\
\hline Oviposition and spawning site & $\begin{array}{l}\text { In wild and aquaria: demersal, adhesive eggs attaching } \\
\text { to aquatic vegetation }\end{array}$ \\
\hline Spawning migration & In wild: none observed \\
\hline Parental care & In aquaria: guarding of spawning sites ${ }^{\mathrm{a}}$ \\
\hline Time to hatching/length at hatching & In aquaria at $25 \pm 1^{\circ} \mathrm{C}: 50 \mathrm{~h} / 2.8-3.4 \mathrm{~mm} \mathrm{LBL}^{\mathrm{b}}$ \\
\hline Length/age at free swimming stage & In aquaria at $25 \pm 1^{\circ} \mathrm{C}: 3.9-4.6 \mathrm{~mm} \mathrm{LBL} ; 5 \mathrm{dph}^{\mathrm{b}}$ \\
\hline Length/age at loss of yolk sac & In aquaria at $25 \pm 1^{\circ} \mathrm{C}: 4.3 \mathrm{~mm} \mathrm{LBL}_{i} \geq 8 \mathrm{dph}^{\mathrm{b}}$ \\
\hline Length/age at first feeding & In aquaria at $25 \pm 1^{\circ} \mathrm{C}: 3.6-3.4 \mathrm{~mm} \mathrm{LBL}^{\circ} 5 \mathrm{dph}^{\mathrm{b}}$ \\
\hline Length/age at metamorphosis into juveniles & In aquaria at $25 \pm 1^{\circ} \mathrm{C}: \geq 9.6 \mathrm{~mm} \mathrm{LBL} ; 70 \mathrm{dph}^{\mathrm{b}}$ \\
\hline Growth rate & $\begin{array}{l}\text { In wild: increased from } 14 \mathrm{~mm} \text { to }>28 \mathrm{~mm} \text { TL over a } 1 \text { yr period } \\
\text { In aquaria at } 25 \pm 1^{\circ} \mathrm{C} \text { : increased from } 2.8 \text { to } 20.6 \mathrm{~mm} \mathrm{LBL} \text { in } 6 \mathrm{mo}^{\mathrm{b}}\end{array}$ \\
\hline Trophic guild and dietary composition & $\begin{array}{l}\text { Microphagic carnivore consuming prey }<5-6 \mathrm{~mm} \text { in length including } \\
\text { zooplankton, aquatic insects, atyid shrimps, terrestrial arthropods and } \\
\text { flying aquatic insects }\end{array}$ \\
\hline
\end{tabular}




\section{CURRENT STATUS AND THREATS}

The majority of extant populations of Nannoperca oxleyana are located in national parks and other protected areas (NSW DPI 2005). However, N. oxleyana remains threatened by degradation of aquatic habitats downstream from reserves (i.e. the creation of sink habitats), disruption to fish passage, water pollution and riparian degradation associated with public access, fire management activities and the introduction of alien and translocated species. For example, some small coastal water bodies such as Spitfire Creek on Moreton Island are situated so close to the eastern surf beach that visitors often stop there to wash their vehicles with fresh water; this can disturb the fragile vegetation associations that provide shelter and habitat for N. oxleyana (Knight \& Arthington 2008). Contaminants from car washing and picnic refuse may also pose a threat to fish in small water bodies, especially those near camping grounds. Management trails traversing shallow streams have the potential to disrupt the connectivity of drainage systems and interfere with the degree to which $N$. oxleyana moves, mixes and interbreeds within some of the more extensive freshwater systems (Arthington 1996, Pusey et al. 2004).

The causes of endangerment discussed above and encroaching urban and agricultural developments also threaten a number of populations occurring on freehold land, particularly those on Queensland's Sunshine Coast and in NSW near Evans Head (Priestly 1995, Knight 2000, 2008, Pusey et al. 2004, NSW DPI 2005). Large expanses of habitat suitable for Nannoperca oxleyana in Queensland and NSW have been destroyed, fragmented or degraded by residential and resort development, road construction, agriculture, forestry, sand mining and water pollution. Some coastal streams now contain introduced weeds such as para grass Brachiaria mutica and support pest fishes such as Gambusia holbrooki (Arthington \& Marshall 1999, Pusey et al. 2004). The distribution of $N$. oxleyana in undisturbed streams near the Richmond River, NSW, has also been truncated in degraded downstream sections modified into sugar cane drains (Knight \& Arthington 2008).

Anthropogenic disturbances may take effect across the full range of habitat scales that are important determinants of the distribution of Nannoperca oxleyana (Knight \& Arthington 2008). The habitat associations of the species documented by Knight \& Arthington (2008) reveal affinities that are particularly relevant to its conservation. Although both lotic and lentic environments provide habitat for $N$. oxleyana, a defining characteristic among inhabited sites is a distinct lack of stream flow. This has implications for habitat protection/management in riverine localities where natural flow variability and/or changes in the flow regimes of regulated rivers and streams may create both low flow and high flow disturbances (Arthington \& Pusey 2003). Unnaturally low flow levels (caused by pumping or an upstream weir or impoundment) can deprive low flow and backwater habitats, or interconnected lakes, of sufficient water, whereas water releases may degrade microhabitat structure by initiating and exacerbating bank erosion, and by scouring or removing important structural elements such as submerged aquatic vegetation (Arthington \& Pusey 2003, Mackay et al. 2003). Maintenance of natural stream habitat structure and patterns of aquatic plant growth in the relatively fragile, sand bed coastal streams supporting this species are high priorities in developing principles for catchment management and fauna conservation.

Drought conditions in eastern Australia over the past $10 \mathrm{yr}$, possibly linked to climate change, have been observed to desiccate important freshwater habitats and place aquatic populations under environmental stress (Bond et al. 2008, Knight 2008). Associated with drought, bushfires and hazard reduction burns and their effects on aquatic systems may threaten populations both within and outside of conservation areas. An intense bushfire in late 2001 resulted in an $89 \%$ reduction in overall fish abundance and a $99 \%$ reduction in the abundance of Nannoperca oxleyana in a small stream near Evans Head in NSW (Knight in press). Fire management activities such as the use of chemicals including surfactants (wetting agents and foaming agents; DECCW 2009), in relatively close proximity to water bodies may degrade fish habitat. Similarly, important aquatic habitats may be used as water abstraction points for fire fighting purposes, thereby reducing water levels, exposing critical microhabitats and potentially directly removing fish. The construction of new, or the upgrading of existing, roads and fire management trails that dissect drainage systems can disrupt the connectivity of $N$. oxleyana habitat.

The alien pest fish Gambusia holbrooki inhabits many eastern Australian coastal drainage systems. This species has invaded approximately $45 \%$ of habitats supporting Nannoperca oxleyana in NSW and also occurs in several Queensland localities (Arthington \& Marshall 1993, 1999, Pusey et al. 2004, Knight 2008). This pest species is a significant threat to N. oxleyana as it may prey upon fish eggs and very young fish and/or compete for food and habitat resources (Arthington \& Lloyd 1989, Arthington \& Marshall 
1993). G. holbrooki may aggressively attack N. oxleyana in the wild, thereby forcing individuals away from optimal habitats (J. T. Knight pers. obs.). This antagonistic behaviour, which may include fin-nipping, has been demonstrated to impact on fin condition, feeding, reproductive success and survival rates of small-bodied fishes in other aquatic systems (Howe et al. 1997, Warburton \& Madden 2003). A translocated, large-bodied piscivore, the Australian bass Macquaria novemaculeata, also threatens several NSW populations of N. oxleyana (Knight in press).

Collection for aquaria is considered a potential threat, particularly affecting small, restricted populations of Nannoperca oxleyana. While collection alone is unlikely to remove entire populations, any reduction in numbers may affect the population's capacity to recover from random events such as drought and wildfire or from interactions with introduced species (Arthington 1996, NSW DPI 2005). Searching and collecting activities can also disturb the fragile coastal streams and wetlands inhabited by N. oxleyana and may act as a potential disease vector, particularly in isolated and pristine areas.

Many of the threatening processes described above frequently coincide and interact in readily accessible and disturbed coastal catchments, and it is possible that synergistic effects could lead to the extirpation of entire populations. Most populations of Nannoperca oxleyana are relatively small, and the species is generally not locally abundant. However, population sizes vary considerably both spatially and temporally (Arthington \& Marshall 1993, Arthington 1996, Knight 2000, Knight et al. 2007a,b). While habitat quality, drought conditions, movement and the seasonality of breeding and recruitment have been shown to be contributing factors (Knight 2000, 2008, Pusey et al. 2004), further understanding of driving variables, such as ecological and environmental tolerances, interactions with introduced species and the influence of stochastic, deterministic and threatening processes on populations is needed to support effective management (NSW DPI 2005).

\section{RECOVERY PLANNING AND MANAGEMENT ISSUES}

A key objective of the National Recovery Plan for Nannoperca oxleyana was to increase scientific knowledge and understanding about the distribution, habitat, life history, ecology and genetics of this species (NSW DPI 2005). The recovery plan became the catalyst for undertaking research to gain a clearer understanding of the conservation biology of $N$. oxleyana and the threats to its survival (Knight et al. 2007a,b, 2009, Knight 2008, Knight \& Arthington 2008, Knight \& Trnski 2011). The recovery plan also outlines a number of management objectives to assist with the protection of $N$. oxleyana populations throughout the species' entire range in NSW and Queensland. However, most of the recovery actions are presently taking place in NSW, with some attention to certain threatened populations in Queensland. Key management actions are discussed below.

\section{Habitat protection}

The recovery plan details the need to investigate and implement options for providing increased protection for key areas of Nannoperca oxleyana habitat (NSW DPI 2005). A key mechanism for formally protecting the habitat of threatened species in NSW is to declare 'critical habitat' under the NSW Fisheries Management Act 1994. Areas eligible to be declared critical habitat include

\footnotetext{
the whole or any part of the habitat of an endangered species, population or ecological community or critically endangered species or ecological community that is critical to the survival of the species, population or ecological community...(NSW Fisheries Management Act 1994, Part 7A Section 220P)
}

In this context, 'habitat' means any area occupied, or periodically or occasionally occupied, by fish or marine vegetation (or both), and includes any biotic or abiotic component.

The proposal to declare critical habitat for Nannoperca oxleyana in NSW includes all public lands where the species is known or likely to occur. This includes parts of certain national parks, crown lands and state forests on the north coast of NSW. The critical habitat proposal includes a $50 \mathrm{~m}$ buffer on public lands either side of identified watercourses to protect habitat utilised during floods and high flow events. The NSW Fisheries Management Act 1994 guides planning under the NSW Environmental Planning and Assessment Act 1979 (EP\&A Act), triggering assessment of any activity with potential to damage critical habitat. Assessment includes the mandatory development of a species impact statement. The draft proposal to declare critical habitat for $N$. oxleyana was publicly exhibited in February/March 2010. Several subsequent issues raised by public authorities are currently being addressed by the NSW Government as part of obligations under the NSW Fisheries Management Act 1994. 


\section{Stakeholder engagement and raising awareness}

An important aspect of the recovery program for Nannoperca oxleyana is ongoing negotiation and communication with public authorities who have responsibility for managing $N$. oxleyana habitat. A large proportion of habitat occurs within national park estate, necessitating liaison with the relevant government authority regarding park management activities. Negotiations have focused on managing threats including run-off originating from unsealed roads, herbicide use, fire management activities and disturbance by recreational users such as 4wheel drivers and campers. The range of measures adopted to lessen impacts on $N$. oxleyana include, for example, avoiding prescribed burning activities during the main breeding season (October to April); utilising a mosaic burning pattern where only a third to a quarter of the wetlands are burnt in any given year; avoiding the pumping of water from $N$. oxleyana habitats; and avoiding the use of fire fighting foam and retardants within $50 \mathrm{~m}$ of $N$. oxleyana habitat.

Some areas of Nannoperca oxleyana habitat managed by local councils have been severely disturbed in the past by a number of activities including the construction and maintenance of drains through dredging, which causes severe disturbance of watercourses and destruction of important fish habitat. A key action of the recovery plan is to provide appropriate knowledge and expertise to assist councils in developing low-impact drain management practices that avoid or minimise the impacts of drain construction and maintenance on $N$. oxleyana populations and habitats (NSW DPI 2005). Detailed information relating to the distribution and breeding patterns of $N$. oxleyana has been provided to councils, and this has assisted in prioritising drainage schemes where $N$. oxleyana issues must be addressed when undertaking maintenance and construction activities. Cases of this type have also assisted with raising the profile of the species and its habitat within relevant local government areas, and promoted consultation with the State government authorities regarding potential impacts of developments and activities. The provision of accurate information regarding the benefits of conservation is also an important mechanism facilitating public engagement. For example, the threat posed by the illegal collection of $N$. oxleyana is addressed by encouraging aquarium enthusiasts to support the recovery plan and become involved in recovery actions, as well as enhanced compliance activities.

\section{Minimising introduced fish impacts}

The recovery plan promotes the reporting and monitoring of introduced fish into environments inhabited by Nannoperca oxleyana and supports measures to reduce their impacts. Emphasis has been placed on documenting and monitoring the distribution and range expansions of species such as Gambusia holbrooki relative to $N$. oxleyana. The NSW Freshwater Fish Stocking Fishery Management Strategy and the Queensland Department of Primary Industries and Fisheries translocation policy are both designed to prevent significant impacts from stocking on $N$. oxleyana populations.

\section{Assessing recovery plan effectiveness}

The primary measure of the success of the national recovery plan will be the down-listing of the threatened status of Nannoperca oxleyana under respective State and Commonwealth legislation. The plan recognises the need for a strategically focused monitoring program to enable the effectiveness of the recovery objectives to be evaluated. A long-term monitoring program has been developed to assess the ongoing status of populations. To date, monitoring surveys in NSW and Queensland have found many populations persisting where previously recorded (Arthington \& Knight 2012).

\section{CONCLUSIONS}

The survival of Nannoperca oxleyana and many other endangered species depends largely upon the ability of humans to stem current rates of anthropogenic climate change and environmental destruction, and to effectively maintain the natural processes governing genetic, organismal and ecosystem diversity. The national recovery plan for $N$. oxleyana provides a framework through which detailed biological information underpins 3 critical components of recovery for any threatened fish species: habitat conservation, invasive species management and government and community engagement in species protection and recovery. Comprehensive recovery efforts based on sound science will also deliver a range of other benefits to the receiving environment and assist in mitigating the freshwater biodiversity crisis currently facing Australia and many other countries. 
Acknowledgements. We thank the agencies who supported these studies over the years, in particular the NSW Department of Trade and Industry, Regional Infrastructure and Services, NSW Department of Environment, Climate Change and Water, Australian Nature Conservation Agency, Australian Research Council, Natural Heritage Trust, Griffith University, Southern Cross University and our many colleagues who provided data or assisted with surveys in Queensland and NSW. All research was undertaken in accordance with sampling permits and animal care and ethics protocols issued by NSW and Queensland State Government authorities, Griffith University and Southern Cross University.

\section{LITERATURE CITED}

Arthington AH (ed) (1996) Recovery plan for the Oxleyan pygmy perch Nannoperca oxleyana. Final report to the Australian Nature Conservation Agency Endangered Species Program. Centre for Catchment and In-stream Research, Griffith University, Nathan

Arthington AH, Knight JT (2012) Oxleyan pygmy perch Nannoperca oxleyana Whitley. In: Curtis LK, Dennis AJ, McDonald KR, Kyne PM, Debus SJS (eds) Queensland threatened animals. CSIRO Publishing, Melbourne, p 123-124

Arthington AH, Lloyd LN (1989) Introduced poeciliids in Australia and New Zealand. In: Meffe GK, Snelson FF (eds) Ecology and evolution of livebearing fishes (Poeciliidae). Prentice Hall, Englewood Cliffs, NJ, p 333-348

Arthington AH, Marshall CJ (1993) Distribution, ecology and conservation of the honey blue-eye, Pseudomugil mellis, in south-eastern Queensland. Final report to the Australian Nature Conservation Agency Endangered Species Program, Vol 1. Centre for Catchment and InStream Research, Griffith University, Nathan

Arthington AH, Marshall CJ (1999) Diet of the exotic mosquitofish, Gambusia holbrooki, in an Australian lake and potential for competition with indigenous fish species. Asian Fish Sci 12:1-8

Arthington AH, Pusey BJ (2003) Flow restoration and protection in Australian rivers. River Res Appl 19:377-395

Bond NR, Lake PS, Arthington AH (2008) The impacts of drought on freshwater ecosystems: an Australian perspective. Hydrobiologia 600:3-16

Burgman MA, Lindenmayer DB (1998) Conservation biology for the Australian environment. Surrey Beatty and Sons, Chipping Norton

DECCW (Department of Environment, Climate Change and Water) (2009) Fire management manual 2009/2010. NSW Department of Environment, Climate Change and Water, Hurstville

Dudgeon D, Arthington AH, Gessner MO, Kawabata Z and others (2006) Freshwater biodiversity: importance, threats, status and conservation challenges. Biol Rev Camb Philos Soc 81:163-182

Duncan JR, Lockwood JL (2001) Extinction in a field of bullets: a search for causes in the decline of the world's freshwater fishes. Biol Conserv 102:97-105

Dunning JB, Groom MJ, Pulliam HR (2006) Species and landscape approaches to conservation. In: Groom MJ, Meffe GK, Carroll CR (senior authors) Principles of conservation biology, 3rd edn. Sinauer Associates, Sunderland, MA, p 419-465
Frankham R (2005) Genetics and extinction. Biol Conserv 126:131-140

Graham BW (2004a) The green coast: the natural environment of the Tweed-Moreton bioregion. Graham BW, Tweed Heads

Graham BW (2004b) Tweed volcanic region: 360 million years ago to the present day. An environmental history of the Beaudesert, Gold Coast, Tweed, Brunswick and Richmond River. Graham BW, Tweed Heads

Hoese DF, Bray DJ, Paxton JR, Allen GR (2006a) Fishes. Australia Part 1. In: Beesley PL, Wells A (eds) Zoological catalogue of Australia, Vol. 35. ABRS and CSIRO Publishing, Melbourne, p 1-670

Hoese DF, Bray DJ, Paxton JR, Allen GR (2006b) Fishes. Australia Part 2. In: Beesley PL, Wells A (eds) Zoological catalogue of Australia, Vol. 35. ABRS and CSIRO Publishing, Melbourne, p 671-1472

Howe E, Howe C, Lim R, Burchett M (1997) Impact of the introduced poeciliid Gambusia holbrooki (Girard, 1859) on the growth and reproduction of Pseudomugil signifer (Kner, 1865) in Australia. Mar Freshw Res 48:425-434

> Hughes J, Ponniah M, Hurwood D, Chenoweth S, Arthington A (1999) Strong genetic structuring in a habitat specialist, the Oxleyan pygmy perch Nannoperca oxleyana. Heredity 83:5-14

IUCN (International Union for Conservation of Nature) (2009) IUCN Red List of Threatened Species, Version 2009.2. Available at www.iucnredlist.org (accessed 3 November 2009)

> Jerry DR, Elphinstone MS, Baverstock PR (2001) Phylogenetic relationships of Australian members of the family Percichthyidae inferred from mitochondrial 12S rRNA sequence data. Mol Phylogenet Evol 18:335-347

Keller K, Brown C (2008) A new sighting of the Oxleyan pygmy perch. Fish Sahul 22:400-404

Knight JT (2000) Distribution, population structure and habitat preferences of the Oxleyan pygmy perch Nannoperca oxleyana (Whitley 1940) near Evans Head, northeastern New South Wales. Honours thesis, Southern Cross University, Lismore

Knight JT (2008) Aspects of the biology and conservation of the endangered Oxleyan pygmy perch Nannoperca oxleyana Whitley. PhD dissertation, Southern Cross University, Lismore

Knight JT (in press) Distribution and conservation status of the endangered Oxleyan pygmy perch Nannoperca oxleyana Whitley in New South Wales. Fisheries Final Report Series. NSW Department of Primary Industries, Taylors Beach

Knight JT, Arthington AH (2008) Distribution and habitat associations of the endangered Oxleyan pygmy perch, Nannoperca oxleyana Whitley, in eastern Australia. Aquat Conserv 18:1240-1254

Knight JT, Butler GL (2004) Conserving threatened Australian fishes: Nannoperca oxleyana and Maccullochella ikei. Fish Sahul 18:50-57

Knight JT, Trnski T (2011) Early development of the endangered Oxleyan pygmy perch Nannoperca oxleyana Whitley (Percichthyidae). Aust Zool 35:895-909

Knight JT, Butler GL, Smith PS, Wager RN (2007a) Reproductive biology of the endangered Oxleyan pygmy perch Nannoperca oxleyana Whitley. J Fish Biol 71:1494-1511

Knight JT, Glasby TM, Brooks LO (2007b) A sampling protocol for the endangered freshwater fish, Oxleyan pygmy perch Nannoperca oxleyana Whitley. Aust Zool 34: $148-157$ 
Knight JT, Nock CJ, Elphinstone MS, Baverstock PR (2009) Conservation implications of distinct genetic structuring in the endangered freshwater fish Nannoperca oxleyana (Percichthyidae). Mar Freshw Res 60:34-44

Lambeck K, Nakada M (1990) Late Pleistocene and Holocene sea-level change along the Australian coast. Palaeogeogr Palaeoclimatol Palaeoecol 89:143-176

Mackay SJ, Arthington AH, Kennard MJ, Pusey BJ (2003) Spatial variation in the distribution and abundance of submersed aquatic macrophytes in an Australian subtropical river. Aquat Bot 77:169-186

Matthews WJ, Marsh-Matthews E (2003) Effects of drought on fish across axes of space, time and ecological complexity. Freshw Biol 48:1232-1253

Meffe GK, Vrijenhoek RC (1988) Conservation genetics in the management of desert fishes. Conserv Biol 2:157-169

Meffe GK, Carroll CR, Groom MJ (2006) What is conservation biology? In: Groom MJ, Meffe GK, Carroll CR (senior authors) Principles of conservation biology, 3rd edn. Sinauer Associates, Sunderland, MA, p 3-25

Morris SA, Pollard DA, Gehrke PC, Pogonoski JJ (2001) Threatened and potentially threatened freshwater fishes of coastal New South Wales and the Murray-Darling Basin. Report to the Commonwealth Fisheries Action Program and the World Wide Fund for Nature. NSW Fisheries Office of Conservation, Cronulla

Neal R, Stock E (1986) Pleistocene occupation in the southeast Queensland coastal region. Nature 323:618-621

NSW DPI (New South Wales Department of Primary Industries) (2005) Oxleyan pygmy perch: recovery plan and background paper. NSW Department of Primary Industries Fisheries Management Branch, Port Stephens Fisheries Centre, Taylors Beach

Olden JD, Kennard MJ (2010) Intercontinental comparison of fish life history strategies along a gradient of hydro- logic variability. In: Jackson DA, Gido KB (eds) Community ecology of stream fishes: concepts, approaches, and techniques. Am Fish Soc Symp 73:83-107

> Ollier CD (1995) Tectonics and landscape evolution in southeast Australia. Geomorphology 12:37-44

Page TJ, Hughes JM (2007) Phylogeographic structure in an Australian freshwater shrimp largely pre-dates the geological origins of its landscape. Heredity 98:222-231

Priestly D (1995) The Oxleyan pygmy perch needs your help. Aust N G Fish Assoc Bull 19:5-6

Pusey BJ, Kennard MJ, Arthington AH (2004) Freshwater fishes of north-eastern Australia. CSIRO Publishing, Melbourne

Sala OE, Chapin FS III, Armesto JJ, Berlow E and others (2000) Global biodiversity scenarios for the year 2100. Science 287:1770-1774

> Sutherland WJ, Adams WM, Aronson RB, Aveling R and others (2009) One hundred questions of importance to the conservation of global biological diversity. Conserv Biol 23:557-567

Unmack PJ (2001) Biogeography of Australian freshwater fishes. J Biogeogr 28:1053-1089

Wager R, Jackson PD (1993) The action plan for Australian freshwater fishes. Report to the Australian Nature Conservation Agency Endangered Species Program. Queensland Department of Primary Industries, Fisheries Division, Brisbane

Warburton K, Madden C (2003) Behavioural responses of two native Australian fish species (Melanotaenia duboulayi and Pseudomugil signifer) to introduced poeciliids (Gambusia holbrooki and Xiphophorus helleri) in controlled conditions. Proc Linn Soc N S W 124:115-123

- Winemiller KO, Rose KA (1992) Patterns of life-history diversification in North American fishes: implications for population regulation. Can J Fish Aquat Sci 49:2196-2218

Submitted: June 6, 2011; Accepted: January 4, 2012

Proofs received from author(s): March 30, 2012 